\title{
PERBAIKAN MUTU DAN PRODUKSI TELUR ASIN PADA KELOMPOK USAHA TELUR ASIN DI SICINCIN, KABUPATEN PADANG PARIAMAN
}

\author{
Deni Novia ${ }^{1)}$, Indri Juliyarsi ${ }^{2)}$ dan Sri Melia ${ }^{3)}$ \\ ${ }^{1)}$ Fakultas Peternakan, Universitas Andalas email: deni.novia@gmail.com \\ ${ }^{2)}$ Fakultas Peternakan, Universitas Andalas email: i.juliyarsi@gmail.com \\ ${ }^{3)}$ Fakultas Peternakan, Universitas Andalas email: sri.melia75@gmail.com
}

\begin{abstract}
ABSTRAK
Sicincin merupakan salah satu produsen telur asin yang cukup besar di Padang Pariaman. Jumlah produsen telur asin di daerah ini berkisar antara 8-10 produsen, dengan produksi harian rata-rata sekitar 500-1500 butir telur untuk satu produsen, namun pada waktu lebaran sampai 2000-5000 butir, namun pemasaran terbesar hanya di daerah ini saja, memiliki rasa khas, disukai sehingga masih terbuka peluang pemasaran yang lebih luas sebagai makanan khas dari Sicincin. Faktor terpenting yang menjadi kendala pemasaran adalah umur simpan telur asin yang pendek (paling lama sekitar 2-3 hari) dan mutu yang kurang konsisten. Metode pelaksanaan kegiatan ini adalah penyuluhan, demonstrasi, pelatihan, konsultasi dan diskusi dilanjutkan dengan evaluasi. Kelompok usaha telur asin Sicincin sangat antusias dengan hadirnya 1) pengenalan teknologi pengolahan dengan berbagai metode yang dapat memperpanjang umur simpan hingga 1 bulan atau lebih dan 2) demonstrasi dan pelatihan berbagai telur asin aneka rasa dengan label dan kemasan yang menarik. Kelompok usaha telur asin di Sicincin disarankan untuk menerapkan teknologi pengolahan dengan metode yang tepat dan aneka rasa telur asin dengan label dan kemasan yang menarik untuk meningkatkan mutu produknya.
\end{abstract}

Kata kunci: Mutu, Pemasaran, Produksi, Produsen telur asin, Umur simpan

\section{QUALITY IMPROVEMENT AND PRODUCTION OF BUSINESS GROUP SALTED EGGS IN SICINCIN, PADANG PARIAMAN REGENCY}

\author{
Deni Novia ${ }^{1)}$, Indri Juliyarsi ${ }^{2)}$ dan Sri Melia ${ }^{3)}$ \\ ${ }^{1)}$ Animal Science Faculty, Universitas Andalas email: deni.novia@gmail.com \\ 2) Animal Science Faculty, Universitas Andalas email: i.juliyarsi@gmail.com \\ ${ }^{3)}$ Animal Science Faculty, Universitas Andalas email: sri.melia75@gmail.com
}

\section{ABSTRACT}

Sicincin is one of the largest producers of eggs in Padang Pariaman. The number of producers of salted eggs in this area ranges from 8-10 producers, with average daily production of about 500-1500 eggs for one producer, but at the time of Eid to 2000-5000 grains, it is intact only in the area alone, has a unique taste, favored and still open wider marketing opportunities as specialties of Sicincin. The most important factor to be the marketing goal is the short shelf life of briny eggs (at most about 2-3 days) with less consistent quality. Methods of implementation of this activity are counseling, demonstration, training, consultation and follow-up discussion with evaluation. Sicincin salted egg business group was very enthusiastic with the presence of 1) introduction of processing technology with various methods that can save shelf life up to 1 month or more and 2) innovation and development of various kinds of flavors with labels and packaging of interest.

Keywords: Quality, Marketing, Production, Producers of salted eggs, Shelf life 


\section{PENDAHULUAN}

Pariaman memiliki 17 Kecamatan, 46 nagari dan 364 korong. Kecamatan yang paling banyak memiliki nagari adalah Kecamatan Nan Sabaris dan Kecamatan Enam Lingkung yang mempunyai 5 (lima) nagari. Posisi astronomis Kabupaten Padang Pariaman yang terletak antara $0011^{\circ}-00$ 49` Lintang Selatan dan 98036“ - 100028“ Bujur Timur, tercatat memiliki luas wilayah sekitar 1.328,79 km 2, dengan panjang garis pantai $60,50 \mathrm{~km} 2$. Luas daratan daerah ini setara dengan 3,15 persen dari luas daratan wilayah Propinsi Sumatera Barat.

Nagari Sicincin merupakan salah satu daerah di Kecamatan Duo Kali Sabaleh Enam Lingkung Kabupaten Padang Pariaman yang berjarak $\pm 52 \mathrm{~km}$ dari kampus Unand Limau Manis Padang, termasuk wilayah yang terkena akibat gempa dengan kerusakan yang cukup berat yang perlu revitalisasi di berbagai bidang. Salah satunya adalah makanan jajanan yang menjadi ciri khas Pariaman yaitu telur asin.

Telur asin bagi masyarakat Padang Pariaman selain sebagai jajanan tetapi juga untuk mencukupi kebutuhan akan protein hewani dalam menu sehari-hari. Setiap daerah persinggahan ataupun objek wisata di Pariaman sudah identik dengan telur asin. Pemasaran telur asin Sicincin sebagian besar di daerah Pariaman, sedangkan pemasaran dari telur asin Sicincin ke daerah Padang, Bukittinggi, Batu Sangkar, bahkan sampai ke
Pakan Baru tapi harus dengan cara yang sangat rumit supaya masih dalam kondisi baik ketika dikonsumsi. Cara tersebut adalah dengan mengulang-ulang perebusan untuk telur yang bersisa supaya telur masih dalam kondisi aman untuk dikonsumsi.

Salah satu pengasinan yang praktis seperti yang dilakukan masyarakat di Korong Bari Kanagarian Sicincin, adalah pengasinan dangan menggunakan medium : garam, abu dapur dan air, untuk 500 butir telur dibutuhkan satu ember abu, $10 \mathrm{~kg}$ garam dan air. Sedangkan untuk pengasinan berikutnya hanya menambahkan $2 \mathrm{~kg}$ garam lagi. Pengasinan cara ini membutuhkan waktu pemeraman yang lebih pendek yaitu 3 hari. Namun kelemahan dari pengasinan cara ini adalah telur asin yang dihasilkan kurang awet, yakni hanya tahan selama 2 hari. Selain itu, rasa asin yang dihasilkan tidak merata, ada yang cukup asin dan ada yang tidak asin seperti telur rebus saja. Sistem penjualan masih sangat sederhana yaitu pagi hari dibawa ke pasar Sicincin kemudian didistribusikan oleh pedagang eceran yang sudah langganan menjualkannya. Kemudian sore harinya dihitung semua hasil penjualan. Telur asin yang diperjual belikan belum memiliki ciri khas pemilik karena belum ada label atau merek.

Sicincin merupakan salah satu daerah produsen telur asin yang cukup besar di Padang Pariaman. Jumlah produsen telur asin yang ada di daerah tersebut berkisar 
sekitar 8-10 produsen, dengan rata-rata produksi per hari sekitar 500 - 1500 butir telur asin. Ini belum termasuk yang membuat perorangan untuk dijualkan sendiri.

Produsen telur asin dengan jumlah produksi yang tinggi diantaranya adalah Karlina, Jannah, Des dan Gus. Produksi telur asin bisa meningkat tajam pada saat-saat tertentu misalnya pada saat lebaran. Pada kondisi ini jumlah produksi telur asin mereka perpengusaha bisa mencapai 2000-5000 butir setiap harinya. Jumlah produksi telur asin yang sedemikian banyak tidak kesulitan bagi mereka untuk mendapatkan bahan bakunya dan memasarkannya, karena sudah mempunyai langganan-langganan sendiri.

Berdasarkan data Badan Pusat Statistik (BPS) tahun 2006, jumlah produksi telur itik di Padang Pariaman berkisar 1.857.290 butir/hari., sedangkan di Kanagarian Sicincin produksi telur itik yaitu 118.840 butir/hari dengan harga telur itik Rp 1500,-/butir. Hal ini menunjukkan potensi yang besar dari daerah tersebut untuk mengembangkan produksi telur asin, dengan bahan baku telur itik.

Tujuan dari kegiatan pengabdian ini adalah : 1) Memberikan pengetahuan kepada pengusaha telur asin Sicincin dan masyarakat setempat yang terkena dampak bencana gempa 2009 tentang pentingnya peningkatan produksi dan mutu telur asin dengan beberapa metode dalam rangka meningkatkan pendapatan sehari-hari untuk meningkatkan nilai gizi dan kesehatan

masyarakat Sumatera Barat. 2) Mensosialisasikan tentang telur asin aneka rasa, pengemasan yang baik dan pelabelan untuk meningkatkan mutu dari telur asin. Hasil kegiatan ini diharapkan menghasilkan telur asin yang berkualitas dalam jangka waktu yang lebih lama.

\section{METODE PELAKSANAAN KEGIATAN}

\section{Kerangka Pemecahan Masalah}

1. Memberikan penyuluhan nilai gizi dan teknik pengawetan telur asin.

2. Melakukan demonstrasi dan pelatihan pembuatan telur asin aneka rasa seperti pada Gambar 1.

\section{Realisasi Pemecahan Masalah}

a. Produsen telur asin yang diwakili oleh Lina, dkk. telah diberikan penyuluhan bersama warga masyarakat sekitar yang berminat tentang pentingnya telur asin untuk memenuhi kebutuhan gizi sehingga perlu lebih dimasyarakatkan lagi konsumsi telur asin ditengah-tengah masyarakat terutama masyarakat yang terkena akibat gempa.

b. Penyuluhan juga terhadap pentingnya membuat telur asin dengan mutu yang standar/tidak berubah-ubah, awet, cita rasa khas dan disukai konsumen.

c. Kemudian mitra diberi pelatihan dan percontohan dalam pembuatan telur asin mulai dari awal proses yaitu pemilihan telur, pengasinan yang tepat, pemberian aneka rasa pada telur asin (Gambar 1), 
pemasakan dan pengemasan, dan Metode Kegiatan

pelabelan.

d. Setelah itu mitra terus dibimbing dan dibina sampai mereka terlatih dalam melaksanakan proses ini. Hal ini akan lebih mantap dengan adanya diskusi dan konsultasi selama pelaksanaan kegiatan.

Partisipasi Mitra dalam Pelaksanaan Program adalah :

a. Mitra mempunyai minat yang tinggi dalam melaksanakan kegiatan dalam bentuk kesediaan bekerjasama dan menerapkan serta mengembangkan produk telur asin bercita rasa khas. Kerjasama yang sinergis dan berkelanjutan dalam proses ini diharapkan antara mitra dengan pelaksana.

b. Mitra menyediakan sarana dan prasarana untuk pelaksanaan kegiatan sedangkan pelaksana memfasilitasi proses, brosur sehingga dapat terlaksana dengan baik.

c. Mitra melaksanakan merealisasikan proses pembuatan telur asin yang baik dan telur asin aneka rasa.

\section{Khalayak Sasaran}

1. Khalayak sasaran adalah kelompok usaha telur asin Sicincin terletak di Korong Bari Kanagarian Sicincin, Kecamatan Duo Kali Sabaleh Enam Lingkung Kabupaten Padang Pariaman.

2. Warga sasyarakat sekitar yang berminat dengan kegiatan ini terutama yang terkena musibah akibat gempa.
Metode pendekatan yang ditawarkan untuk mendukung realisasi program Ipteks bagi Masyarakat adalah :

a. Penyuluhan

Penyuluhan merupakan cara yang paling baik untuk memberikan pengetahuan kepada masyarakat. Pelaksanaan kegiatan mencakup penyediaan brosur-brosur yang berkaitan dengan:

- Informasi tentang tingginya nilai gizi telur asin sebagai sumber protein hewani dengan daya cerna tinggi disamping itu kandungan asam lemak omega 3 yang dominan dalam lemak kuning telur sebagai nutrisi otak untuk kecerdasan.

- Informasi proses pembuatan telur asin yang lebih awet dengan daya simpan sampai 1 bulan dan bagaimana menjaga telur supaya tetap bisa dipertahankan mutunya sampai ketangan konsumen untuk dikonsumsi.

- Informasi tentang pentingnya pengemasan dan pelabelan dan bagaimana kemasan pangan yang cocok untuk produk telur asin yang aman dan menarik. Pembagian brosur ini dilakukan sebelum penyuluhan dimulai, sehingga diharapkan hasil penyuluhan yang maksimal nantinya. 


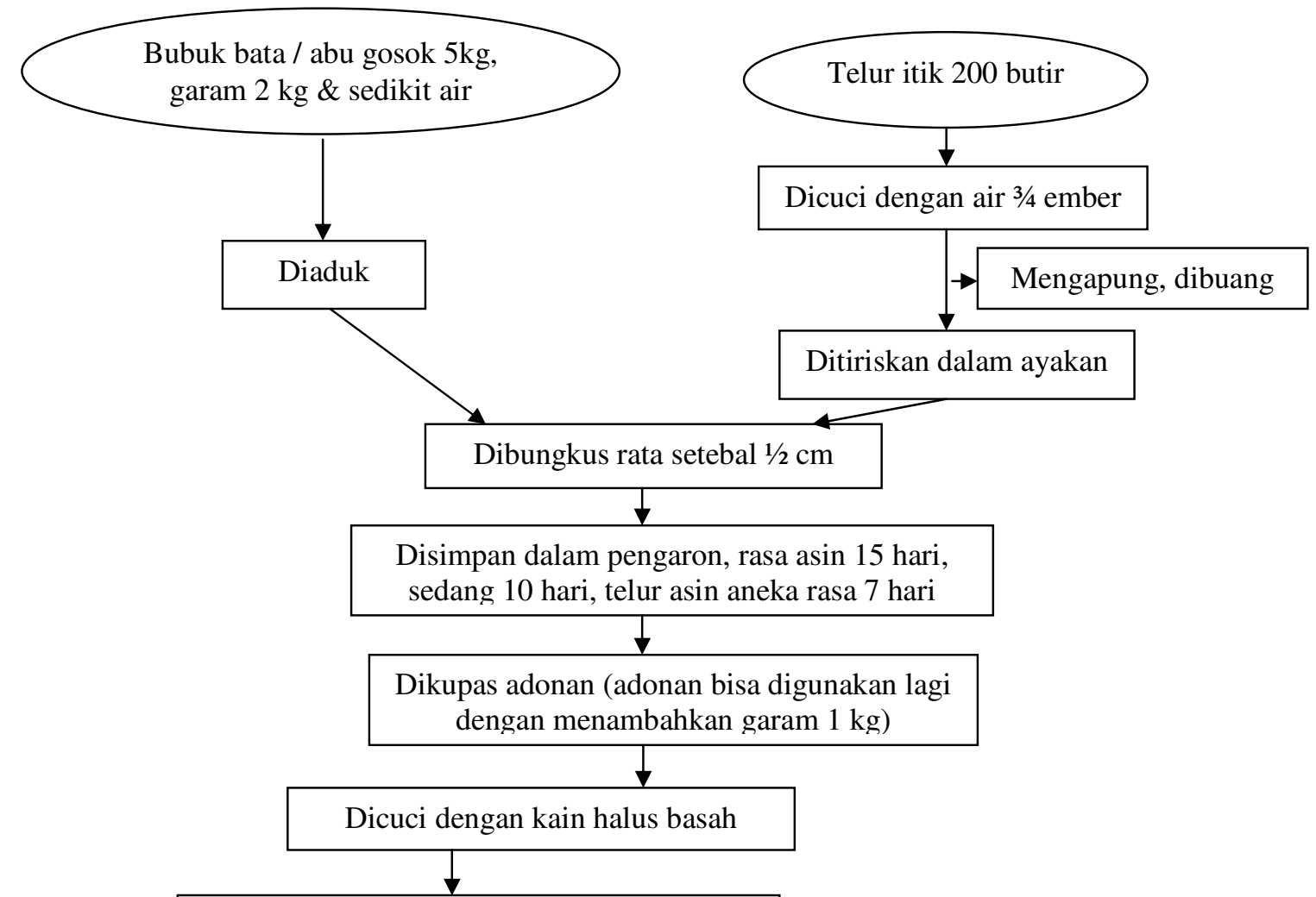

Dilubangi telur, suntik $3 \mathrm{ml}$ aneka rasa sedikit-demi sedikit, kedalaman $2,5 \mathrm{~cm}$ pada daerah putih telur

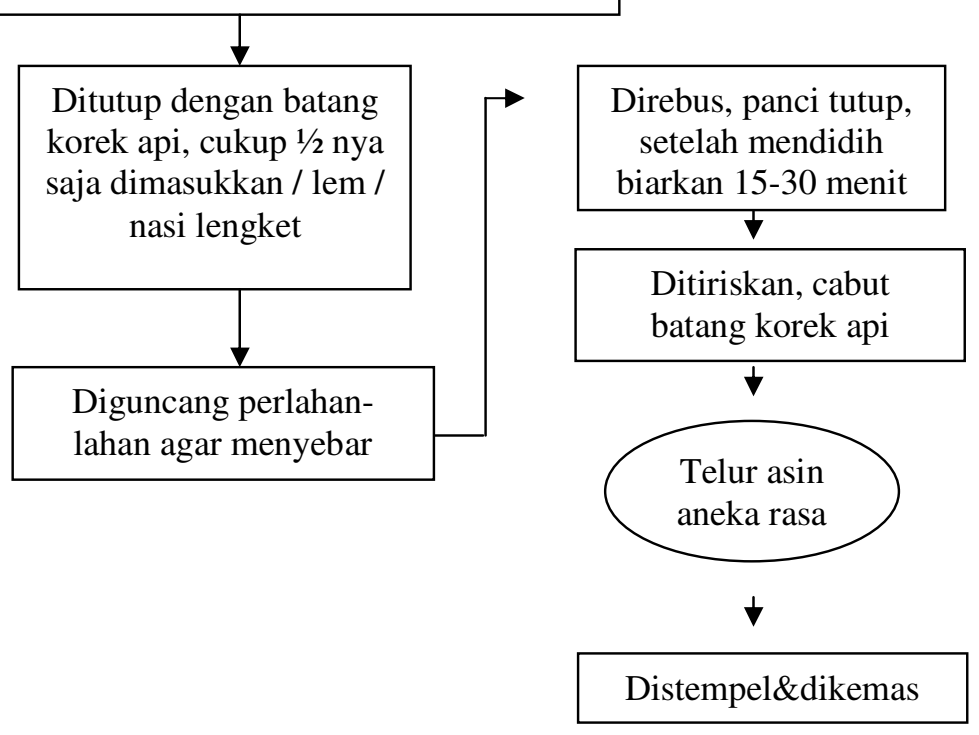

Gambar 1. Diagram Alir Pembuatan Telur Asin 
b. Pelatihan dan Percontohan

Pada kegiatan ini akan diperagakan atau didemonstrasikan :

- Proses pembuatan telur asin dengan proses pembaluran dari bubuk bata, abu gosok dan garam (3:2:1) dengan lama pembaluran 6 hari akan menghasilkan telur asin yang tahan sampai 7 hari.

- Proses pembuatan telur asin dengan memanfaatkan limbah mengandung tannin seperti dari kulit bawang merah ataupun sabut kelapa atau air sisa penirisan getah gambir untuk memperpanjang umur simpan telur asin menjadi 1 bulan.

- Proses pembuatan telur asin sangrai dan telur asin oven untuk menghasikan telur asin modifakasi proses pemasakan.

- Pembuatan telur asin aneka rasa (Gambar 1) yaitu dari rempah-rempah alami seperti jahe, sereh, kayu manis, dll.

Kemudian dicontohkan mengenai pelabelan, pengemasan produk

c. Pembimbingan dan Pembinaan

Perwakilan dari produsen telur asin sekitar 2 orang dibimbing dan dibina untuk membuat telur asin berkualitas. Proses ini dilakukan hingga mereka trampil untuk menerapkan secara mandiri dan akan dilakukan pemantauan secara periodik apakah produktivitas sudah meningkat dan jaringan daerah pemasarannya sudah bertambah melalui koordinasi dengan ketua kelompok produsen yang telah ditunjuk sebelumnya.

d. Diskusi dan Konsultasi

Pada saat penyuluhan, pelatihan atau percontohan dan pembinaan dilakukan diskusi-diskusi dan konsultasi antara pelaksanaan kegiatan dengan mitra telur asin tentang pelaksanaan teknologi yang diterapkan dan kendala yang dihadapi, untuk lebih memantapkan hasil kegiatan Ipteks bagi Masyarakat ini.

e. Pelestarian Kegiatan

Setelah kegiatan selesai dilaksanakan, diharapkan ketua kelompok dan anggotanya dapat melanjutkan kegiatan melalui koordinasi dengan pelaksana kegiatan.

f. Evaluasi Kegiatan

Kegiatan dievaluasi secara periodik sekali dua bulan. Bulan pertama dan kedua pelaksanaan kegiatan. Bulan ketiga dilakukan evaluasi, kemudian bulan kelima dan bulan ke tujuh untuk mengetahui tercapainya sasaran kegiatan atau tidak.

\section{g. Laporan Kegiatan}

Laporan kegiatan disusun dan dibuat selama proses kegiatan sampai selesainya kegiatan diakukan. Hal ini untuk dokumentasi tertulis mengenai kegiatan yang telah dilakukan.

\section{Lokasi, Waktu dan Durasi Kegiatan}

Pengabdian ini dilaksanakan di Bari Tangah, Nagari Sicincin, Kec. 2 x 11 Enam Lingkung, Kab.Padang Pariaman, pada tahun 2011 selama 5 bulan. 


\section{HASIL DAN PEMBAHASAN}

Potensi Telur Asin di Korong Bari

\section{Kanagarian Sicincin}

Telur asin Sicincin merupakan jajanan khas yang digemari baik masyarakat setempat maupun sebagian besar orang yang melintasi Pariaman untuk menuju kota tujuaannya. Kegemaran telur asin ini terlihat dari produksi telur asin yang tinggi oleh kelompok usaha telur asin sekitar 500 sampai 1500 butir setiap hari da hari biasa dan 2000 sampai 5000 butir pada saat lebaran. Kelebihannya adalah bahan baku telur itik selalu tersedia karena produsen sudah sistem langganan dan telur itik langsung diantar ke rumah produsen. Hal ini ditunjang juga oleh produksi telur itik di Padang Pariaman yang cukup tinggi sehinggi sangat potensial untuk dikembangkan.

Kelompok usaha telur asin sicincin yang baru dibentuk, langsung dikelola oleh seorang ibu rumah tangga pengusaha telur asin bernama Karlina. Telur asin Karlina sudah mulai berproduksi dari tahun 2002, sebelumnya Karlina bekerja di pembuatan telur asin Des. Kemudian Karlina mulai memproduksi telur asin sendiri dengan produksi awal sekitar 60 sampai 90 butir sehari yang merupakan usaha keluarga. Dalam berproduksi Karlina selalu konsisten menjaga keasinan telur yang diproduksinya terutama diwaktu pesanan meningkat dengan tajam pada lebaran. Karlina tidak mau menjual telur asin yang tidak asin kepedagang ataupun kekonsumen langsung, berbeda dengan produsen lainnya. Berjalannya waktu tahun 2009 produksi Karlina sudah mencapai 500-1000 butir/hari. Namun tahun 2011 produksi Karlina meningkat dengan pesat yaitu 1500 butir/hari. Kunci kesuksesan Karlina terletak dari komitmennya menjaga keasinan telur, mutu dan harga telur asin yang murah ke pedagang dan konsumen.

Telur itik mentah yang diantarkan peternak ataupun pengumpul langsung ke rumah Karlina yang beralamat di Bari Tangah, Nagari Sicincin, Kec. 2 x 11 Enam Lingkung, Kab.Padang Pariaman. Harga telur itik mentah adalah Rp 1700/butir untuk telur itik Jawa dan Rp 1800/butir untuk telur itik biasa. Telur itik bersumber dari Padang Pariaman, Payakumbuh, dan telur itik Jawa. Sedangkan harga jual Karlina kepada pedagang hanya Rp 2.000/butir. Kemudian pedagang akan menjualkan kekonsumen dengan harga bervariasi mulai dari $\mathrm{Rp}$ 10.000,;/4 butir sampai Rp 10.000,-/3 butir atau diserahkan kepedagang harga jual telur asin.

Karlina mempunyai langganan tetap yang membeli dan menjemput telur asin ke Karlina dalam jumlah besar untuk dijualkan kembali dan ada juga penjual telur asin tetap yang mengambil telur asin pada Karlina ketika sudah sampai di pasar Sicincin. Biasanya sore hari telur yang tidak habis terjual oleh pedagang ataupun retak 
dikembalikan pada Karlina. Telur yang retak akan dijual lebih murah oleh Karlina dan telur asin yang tidak habis pada hari itu akan direbus kembali oleh Karlina keesokan harinya untuk dijualkan kembali.

Kebutuhan telur asin terutama hanya untuk memenuhi kebutuhan daerah Sicincin, terlihat dari jumlah penjualan terbesar tiap harinya. Sedangkan penjualan telur asin Karlina ada juga yang dibawa oleh langganan tetapnya ke objek-objek wisata di Pariaman dan Padang Pariaman serta beberapa objek wisata di Sumatera Barat. Ada juga konsumen yang membelinnya untuk oleholeh ke Pekanbaru, Jakarta tapi sayangnya tidak tahan lama.

Peningkatan Mutu dan Produksi Telur Asin

Telur merupakan hasil ternak yang mempunyai andil besar dalam mengatasi masalah gizi yang terjadi di masyarakat. Hal ini dimungkinkan karena telur sarat akan zat gizi yang diperlukan untuk kehidupan yang sehat. Zat-zat gizi yang ada pada telur sangat mudah dicerna dan dimanfaatkan oleh tubuh. Itulah sebabnya telur dianjurkan untuk dikonsumsi oleh orang yang sedang sakit atau dalam proses penyembuhan, anak-anak yang dalam masa pertumbuhan, ibu hamil dan menyusui, serta para lansia.

Pengasinan dikatakan berhasil dengan baik, jika telur asin yang dihasilkan bersifat : stabil (dapat disimpan lama tanpa banyak mengalami perubahan), aroma dan rasa telur asin terasa dengan nyata dan penampakan putih dan kuning telur yang baik. Biasanya kuning telur kelihatan masir atau berminyak disekeliling kuning telur dan terasa seperti berpasir.

Produksi telur asin Sicincin oleh ketua kelompok Karlina termasuk paling banyak diantara produsen telur asin lainnya. Produksi perharinya dengan jumlah 1500 butir di hari biasa dan pada hari libur bisa sampai 2000 butir perharinya. Sedangkan pada hari lebaran penjualannya melonjak drastis sampai 5000 butir/ harinya. Sehingga Karlina harus mempunyai persediaan telur yang telah diasinkan dalam jumlah yang sangat banyak menggunakan wadah penyimpanan berupa peti-peti kayu. Proses produksi telur asin Sicincin seperti Gambar 2 dan dokumentasi proses pembuatan dapat dilihat pada Gambar 3.

Permasalahan yang sering timbul dalam proses pengasinan telur itik dengan cara perendaman dalam larutan abu dan garam adalah rasa asin yang tidak seragam yaitu bagian atasnya kurang asin. Pengasinan ini berlangsung 3-4 hari malah ada produsen yang mengasinkan selama 1-2 hari sehingga masih sedikit asin. Hal ini dapat diatasi dengan mengasinkan lebih lama sampai 8 hari seperti penelitian Novia [1] menggunakan abu kayu dan abu sekam dapat meningkatkan kandungan mineral telur asin mentah yang dihasilkan. Hasil penelitian Novia [2] supaya telur asin yang dihasilkan 
merata asinnya dapat menggunakan metode pembaluran atau pencelupan dalam larutan abu. Metode pembaluran dapat dilakukan dengan membalurkan pasta abu/bata dan garam ke setiap butir telur dengan ketebalan sekitar 3-5 mm, sedangkan metode pencelupan dengan mencelupkan telur ke dalam pasta abu, garam yang agak encer dari pasta kemudian diasinkan selama 7 hari.

Alternatif bahan baluran dapat menggunakan kombinasi abu kayu dan kapur (2-2) untuk menghasilkan telur asin dengan

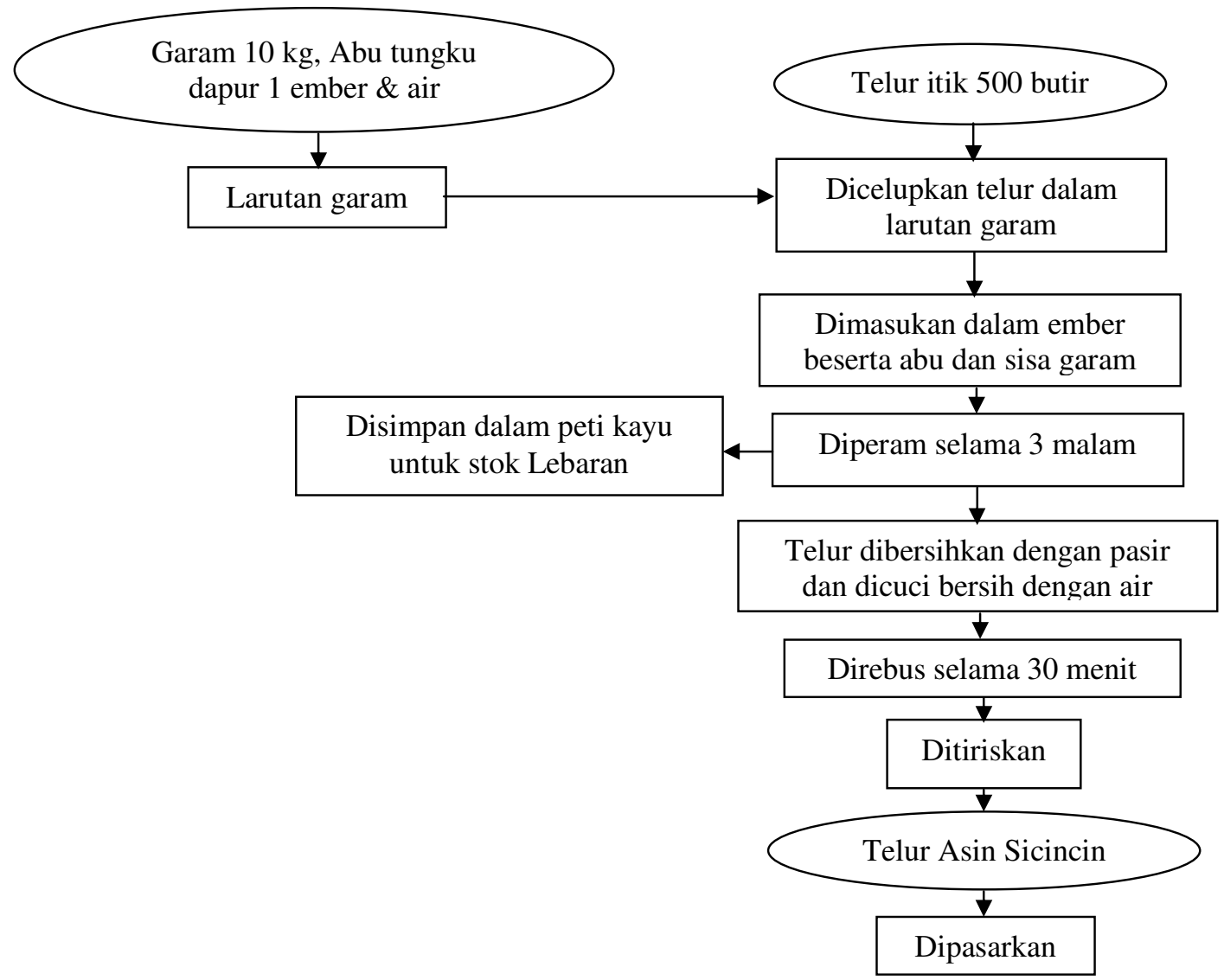

Gambar 2. Diagram Alir Pembuatan Telur Asin Sicincin peningkatan kadar kalsium dan organoleptik [3].

Alternatif proses pembuatan telur asin sudah didapatkan beberapa produsen dengan cara baluran bata tapi tidak diterapkan dengan alasan kurang praktis dan rasanya kurang bersaing dengan cara tradisional yang telah dilakukan. Adapun alternatif yang tepat untuk mengatasi rasa kurang asin bagian atas wadah adalah dengan mengasinkan lagi telur asin bagian atasnya kembali supaya lebih asin. 

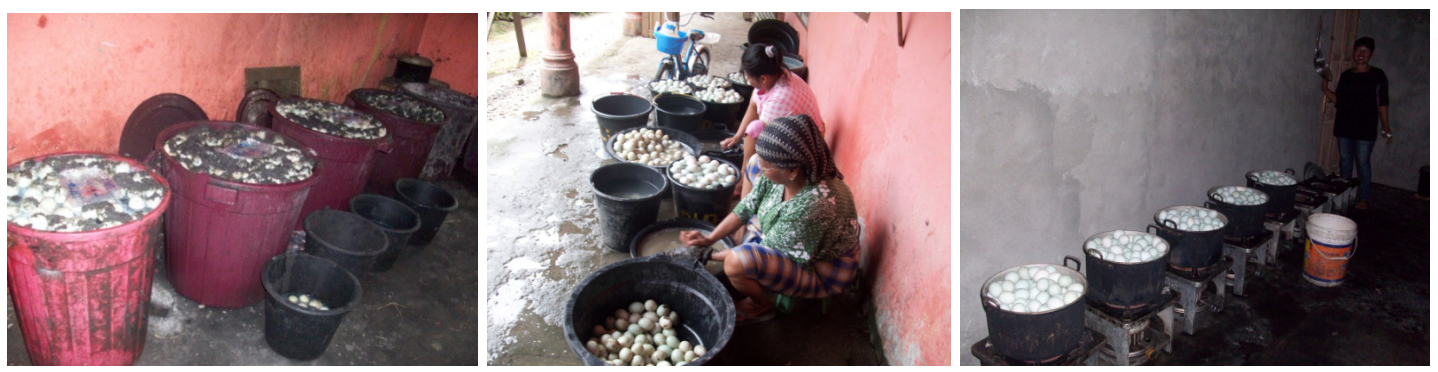

Gambar 3. Proses Produksi Telur Asin Sicincin (dari kiri kekanan : pengasinan, pencucian, perebusan)
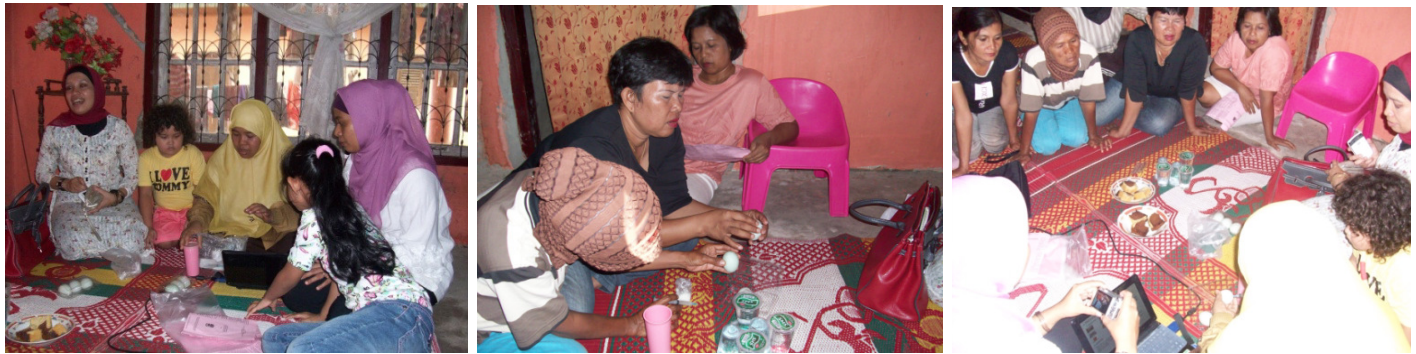

Gambar 4. Dokumentasi Pengabdian (dari kiri ke kanan : demonstrasi, pelatihan, dan antusiasme pengusaha)

Telur asin rebus sicincin mempunyai daya tahan simpan yang pendek, hanya tahan 2 hari. Hal inilah yang menyebabkan pemasaran telur asin tidak dapat terlalu jauh atau perlu penanganan yang ekstra untuk memasarkannya ke daerah yang lebih jauh. Penyuluhan telur asin tentang nilai gizi dan pengawetannya mendapat sambutan hangat oleh kelompok usaha telur asin sicincin.

Telur asin dapat diperpanjang umur simpannya dengan berbagai cara : 1) Modifikasi proses pemasakan : telur asin sangrai, telur asin oven dan telur asin asap dapat memperpanjang umur simpan telur asin sampai 1 bulan, 2) Penutupan pori kulit telur asin dengan zat mengandung tannin seperti : kulit bawang merah,teh, daun jambu biji, lidah buaya, air sisa penirisan getah gambir, dapat memperpanjang umur simpan telur asin 14 - 63 hari, 3) Pengemasan yang tepat dan menarik. 4) Menjual telur asin mentah.

Adapun pembuatan telur asin sangrai yaitu dengan mengasinkan telur asin terlebih dahulu kemudian telur direbus dan selanjutnya disangrai selama 1 jam. Sosialisasi pembuatan telur asin sangrai sudah didapatkan pengusaha telur asin sicincin namun tidak diterapkan dengan alasan kurang praktis.

Telur asin oven dimasak dengan cara pengovenan selama 6 jam suhu $90^{\circ} \mathrm{C}$ dapat tahan sekitar 38 hari, tanpa direbus terlebih dahulu [4]. Teknologi ini juga dapat mempertahankan penurunan kadar protein dari telur asin oven yang dihasilkan. Berdasarkan hasil penelitian dapat disimpulkan bahwa suhu pengovenan telur asin yang paling baik setelah penyimpanan 25 hari adalah pada suhu $90^{\circ} \mathrm{C}$ dengan kadar protein $13.47 \%$, nilai organoleptik rasa 2.47 , 
aroma 2.38 dan tekstur 2.66 [5].

Pembuatan telur asin asap dilakukan dengan memasak telur asin memanfaatkan panas dari asap sabut kelapa. Proses pengasapan termasuk dalam pengasapan dingin karena pengasapan dilakukan tidak langsung ke produk melainkan mengalirkan asap ke telur asin. Proses pemasakan telur dengan cara pengasapan selama 8 jam dapat mempertahankan penurunan protein dan memperpanjang umur simpannya sampai 37 hari masih disukai panelis [6]. Hasil penelitian Novia dan Melia [7] pembuatan telur asin asap dengan lama penyimpanan selama 23 hari dengan pengasapan selama 14 jam merupakan perlakuan terbaik dalam mempertahankan mutu mikrobiologis telur asin asap dengan kadar air 61.44\%, pH 7.24, total koloni paling rendah $6.2 \times 10^{4} \mathrm{CFU} / \mathrm{g}$, masih dibawah $10^{6}$ (layak dikonsumsi).

Pembuatan telur asin oven dan telur asin asap membutuhkan alat tambahan berupa alat oven dan seperangkat alat pengasapan telur. Hal ini belum diterapkan pengusaha yang masih kewalahan dalam mencukupi permintaan pasar dalam jumlah besar.

Pengawetan telur dengan prinsip penutupan pori kulit telur dengan zat mengandung tanin dilakukan dengan cara membuat ekstrak yang mengandung tanin dengan merebusnya terlebih dahulu kemudian didinginkan dan telur yang telah diasinkan direndam dalam larutan ekstrak. Setelah itu telur asin ditiriskan dan direbus.
Metode-metode pengawetan telur utuh mentah bertujuan untuk mempertahankan kandungan air dan karbondioksida yang terdapat dalam telur selama mungkin dan mempertahankan kegiatan mikroba. Pada pengawetan telur utuh matang (misalnya telur asin dan telur pindang), selain untuk memperpanjang masa simpannya, juga dikehendaki citarasa yang khas [8].

Pengabdian pengawetan telur ayam ras segar menggunakan air sisa penirisan getah gambir di Peternakan Agung Abadi Kec.Harau Bab. 50 Kota dapat mempertahankan mutu telur segar selama satu bulan dengan lama perendaman 1 jam [9]. Pengawetan telur asin dengan perendaman dalam air sisa penirisan getah gambir selama 1 jam dapat mempertahankan umur simpan telur asin rebus sampai 63 hari [10].

Penelitian perendaman telur asin dalam larutan kulit bawang selama 1 hari dapat memperpanjang umur simpan dari telur asin rebus [11]. Selain itu, pemanfaatan larutan bawang merah untuk pembuatan telur asin telah dilakukan pada pengusaha telur asin Quds kec.Pauh Padang sebagai salah satu cara untuk memperpanjang umur simpan dari telur asin [12].

Bahan alami lain yang dapat dimanfaatkan adalah lidah buaya. Lidah buaya dengan pengenceran 1:2 (lidah buaya:air) v/v dapat memperpanjang umur simpan telur asin rebus sampai 19 hari [13]. 
Pengawetan telur asin selain dalam bentuk rebus dapat dilakukan dalam bentuk mentah untuk dipasarkan dalam kondisi mentah sehingga konsumen yang memberli dari daerah lain sebagai oleh-oleh dapat mengkonsumsinya dalam keadaan panas setelah direbus sendiri. Hasil penelitian pengawetan telur asin dalam air sisa penirisan getah gambir dari Pesisir Selatan dengan pemanasan suhu $95^{\circ} \mathrm{C}$ dapat memperpanjang umur simpan telur asin mentah sampai 42 hari [14].

Pengawetan telur asin dengan memanfaatkan senyawa tanin sulit didapatkan di daerah Sicincin seperti air sisa penirisan getah gambir dan kulit bawang. Selain itu senyawa tanin akan mengubah warna kerabang telur itik menyerupai telur ayam yang akan menurunkan nilai telur ditingkat konsumen sehingga belum diterapkan pengusaha telur asin sicincin.

Telur asin untuk pemasaran yang lebih luas perlu dilakukan pengemasan yang tepat supaya telur tetap awet. Telur asin yang telah pecah ataupun retak tidak tahan lama walaupun sudah diawetkan dengan berbagai tekhnik. Pengemasan dan pelabelan harus dikerjakan sekaligus supaya telur asin dapat lebih dikenal oleh konsumen.

Pengabdian pada pengusaha telur asin sicincin berupa demonstrasi dan pelatihan pembuatan telur asin aneka rasa dengan pelabelan dan pengasinan juga mendapat antusias dari peserta. Menurut Warisno [15] telur asin dapat divariasikan rasanya tidak hanya asin tapi ada rasa lain yang khas. Proses penambahan rasa dilakukan setelah telur asin diasinkan terlebih dahulu. Beberapa rasa dapat ditambahkan yaitu rasa buahbuahan dengan jalan menginjeksikan rasa ke dalam telur asin mentah (Gambar 1), misalnya rasa strawberi dilarutkan dulu dalam air hangat kemudian diambil $3 \mathrm{ml}$ dan diinjeksikan ke dalam putih telur dengan memutar telur. Setelah itu diputar seperti angka delapan beberapa kali supaya rasa bisa tersebar merata. Terakhir, bekas injeksi ditutup dengan kapur sirih atau nasi lengket, setelah itu dapat direbus menjadi telur asin rasa strawberi.

Proses penambahan rasa dapat pula dilakukan dengan menambahkan ekstrak rasa ke dalam baluran telur asin, seperti jahe sehingga rasa akan menyerap masuk selama proses pengasinan telur. Cara ini kurang ekonomis untuk jahe dengan harga yang cukup mahal. Namun dapat juga ditambahkan kunyit putih dengan harga yang lebih murah terutama Padang Pariaman banyak terdapat kunyit putih yang tidak termanfaatkan. Cara ini akan menghasilkan pangan fungsional yaitu telur asin yang tinggi kandungan antioksidannya.

Pelabelan penting untuk identitas produk apalagi kalau akan dijual dalam jumlah yang lebih besar dengan kemasan yang menarik. Pelabelan dapat dalam bentuk stiker kecil dan besar maupun stempel kecil langsung pada 
telur asin yang dihasilkan. Sejauh ini produsen belum melakukan pelabelan dengan alasan rasa dari telur yang belum konsisten asinnya. Dokumentasi kegaitan pengabdian dapat dilihat pada Gambar 4.

\section{KESIMPULAN}

Kelompok usaha telur asin Sicincin sangat antusias dengan adanya 1) pengenalan teknologi pengawetan dengan berbagai macam metode yang dapat memperpanjang umur simpan sampai 1 bulan bahkan lebih dan 2) demonstrasi dan pelatihan pembuatan telur asin aneka rasa dengan pelabelan dan pengemasan yang menarik. Kelompok usaha telur asin menemukan pemecahan dari permasalahan yang selama ini dihadapi yaitu umur simpan telur asin yang pendek dan pemasaran sebagian besar hanya didaerah Pariman saja.

\section{SARAN}

Disarankan kelompok usaha telur asin sicincin dapat mengaplikasikan teknologi pengasinan yang tepat, pengawetan dan pembutan telur asin aneka rasa dengan pelabelan dan pengemasan yang menarik untuk meningkatkan mutu dan produksi mereka.

\section{UCAPAN TERIMAKASIH}

Penulis mengucapkan terimakasih kepada LPPM yang telah mendanai pengabdian ini melalui Dana Dipa Rutin Universitas Andalas, tahun anggaran 2011, Nomor. 24/Un.16/Pm/ Dipa-Kompetitif/IV2011 serta semua pihak yang telah membantu hingga kegiatan ini dapat terlaksana dengan baik.

\section{REFERENSI}

[1] Novia, D., S. Melia and I. Juliyarsi. 2014. Utilization of ash in the salting process on mineral content raw salted eggs. Asian Journal of Poultry Science. 8(1):1-8.

[2] Novia, D., A. Sandra dan R. Ferlindo. 2012. Kajian proses pengasinan terhadap nilai gizi dan organoleptik telur asin. Laporan Penelitian Dosen Muda. Universitas Andalas.

[3] D. Novia, S. Melia, dan Mutiara. 2016. Kombinasi abu kayu dan kapur pada proses pengasinan terhadap karakteristik fisikokimia dan nilai organoleptik telur asin. Jurnal Peternakan Indonesia (JPI). 18(1):2935.

[4] Novia, D., S. Melia, dan N.Z Ayuza. 2012. Studi suhu pengovenan terhadap umur simpan telur asin. Jurnal Peternakan Indonesia. 14(1):263-269.

[5] Novia, D., S. Melia, dan N.Z. Ayuza. 2011. Kajian suhu pengovenan terhadap kadar protein dan nilai organoleptik telur asin. Jurnal Peternakan. 8(2):70 - 76.

[6] Novia, D., I. Juliyarsi, dan G. Fuadi. 2012. Kadar protein, kadar lemak dan organoleptik telur asin asap berbahan bakar sabut kelapa. Jurnal Peternakan. 9(1):35 - 45.

[7] Novia, D. dan S. Melia. 2010. The effect time of smoking process and storage of smoking salting egg with material coco fiber for water, $\mathrm{pH}$, bacterial colony forming and formaldehide. International Seminar on Food And Agricultural SciencesISFAS2010. Hal : 243-249.

[8] Muchtadi, D. 2009. Prinsip Teknologi Pangan. Cet-1. Penerbit Alfabeta. Bandung.

[9] Novia, D., I. Juliyarsi dan A.A. Putra. 2010. Pengawetan telur dengan menggunakan air sisa penirisan getah gambir di Peternakan Agung Abadi 
Kec Harau Kab.50 Kota. Warta

Pengabdian Andalas (Jurnal Ilmiah

Pengembangan dan Penerapan Iptek).

XVI(25): 109-121

[10] Novia, D., I. Juliyarsi, A. Sandra, Yuherman and R. Muhammad. 2014. Soaking salted eggs in gambier liquid waste inhibit bacterial growth. Pakistan Journal of Biological Sciences. 17(3):424-428.

[11] Novia, D., I. Juliyarsi, P. Andalusia. 2011. Evaluasi total koloni bakteri dan cita rasa telur asin dengan perlakuan perendaman ekstrak kulit bawang (Allium ascalonicum). Jurnal Peternakan Indonesia. 13 (2):92-98.

[12]Melia, S., I. Juliyarsi dan D. Novia. 2011. Pemanfaatan ekstrak tanin dari limbah kulit bawang sebagai pengawet alami pada usaha telur asin Quds di Kelurahan Pisang, Kec.Pauh.Padang. Warta Pengabdian Andalas (Jurnal Ilmiah Pengembangan dan Penerapan Iptek). XVII(26) : 42-52.

[13] Allismawita, D. Novia, I. Putra. 2014. Evaluasi total koloni bakteri dan umur simpan telur asin yang direndam dalam larutan lidah buaya (Aloevera barbadensis Miller). Jurnal Peternakan Indonesia. 16(2):71-77.

[14] Novia, D., E. Vebriyanti and H.F. Hakim. 2017. Evaluation of heating the gambier liquid waste on the quality of raw salted eggs. International Journal of Poultry Science, 16(9): 369-373.

[15] Warisno. 2005. Membuat Telur Asin Aneka Rasa. Agro Media Pustaka, Jakarta 